\title{
THE QUALITY INFLUENCE OF GOAT MILK AND TECHNOLOGY OF PRODUCTION ON THE
} CHARACTERISTIC OF THE GOAT MILK CHEESE OF THE CAMEMBERT TYPE

\author{
POPOVIĆ-VRANJEŠ ANKA*, JOVANOVIĆ $\mathrm{S}^{* *}$, SAVIĆ MILA**, KRAJINOVIĆ M*, \\ KASALICA ANKA***, MIOČINOVIĆ DRAGICA*** and KECMAN JELENA* \\ *Faculty of Agriculture, Department of Animal Science, Novi Sad, Serbia; \\ **University of Belgrade, Faculty of Veterinary Medicine, Serbia; ***Insitute of Dairy, Belgrade
}

(Received 9. January 2008)

The purpose of this work was to provide high quality goat milk production of a goat cheese of Camembert type. The results of the work are showing us that in row milk, the total number of bacteria was in a range from $4 \times 10^{3}$ to $20 \times 10^{3} / \mathrm{mL}$, and the number of somatic cells is from $230 \times 10^{3}$ to $390 \times 10^{3} / \mathrm{mL}$. Bacteria Listeria monocytogenes and Bacillus cereus were not found. Milk did not contain antibiotic residues, mycotoxins, pesticides, hard metals or radionucleoides. From the hygienic view, the milk was healthy and safe. Milk from German does i.e. the race of the studied goat had $3.2 \pm 0.10 \%$ of fat and a mild taste and smell. The part of the middlechain fatty acids (C6-C12) was 15.31\% and capric acid was $6.29 \%$. Polyunsaturated fatty acids were $26.69 \%$ and linolic-acid $3.1 \%$. According to protein content, as well as other indicators of the contents and physical-chemical characteristics, the milk was technologically suitable for cheese production. The selection of the cultures MM100 and TA052, as well as the mold Geotrichum condidum and Penicillium camemberti and the tehnologyc process with the HACCP system implemented, enabled the production of a healthy and safe cheese with the well known characteristics.

Key words: the goat milk, Camembert, technology

\section{INTRODUCTION}

In Serbia, goat breeding is in expansion and that is a sector of production which, for many reasons, has to be developed. The cheese made from goat's milk has a specific unusual taste and aroma, which it makes very respectable, modern gastronomic speciality in spite of tradition. Especially, the cheese with white noble molds of the type Camemberta, has a high rating. The German doe race of goat, which we were milking for cheese production, in the third lactation, produced 769 L milk and $24.61 \mathrm{~kg}$ of fat. Outside factors, especially feeding, have an influence on the quantity of milk fat and its structure (Ferh and Delage, 1973). The fat in the goat milk does not contain carotene, so the cheese has an extremely white colour. Because of smaller fat globules (Attaie et al., 2000), the goat's milk fat curdles well 
and there are less losses of milk fat in the whey. In goat milk the connection between the fat content and the concentration of the fatty acids is established. The concentration of fatty acids is larger in the autumn than in spring (St-Gelais et al., 2002). The fat in goat's milk contains, more fatty acids, like caprionic, capril and capriolic, which give the specific flavour to the product (Salvadore del Prato, 2001; Popović-Vranjes et al., 2005). It is considered that $P$. camemberti is more suitable for the production of Camembert if under lipolys the fats released the liquid fatty acids, like caprilic, from which in further transformation we get the metil-nonil ketones. Beside this ketone in Camembert there are other ketones, like methyl-n propyl ketone (Scott, 1986). Fats have a very important role in the cheese microstructure (St-Gelais, 2002). The protein content is very important for the returns and for the quality of the cheese. Goat's milk clots faster, but the curd is softer which is connected with the smaller protein micelle and smaller particles such as casein (Alichandis and Polychroniadou, 1997). The characteristics of the milk curdle depend from the season and the breed of the goat (St-Gelais et al., 2002). The goat milk is rich with nonprotein nitrogen (6\%) opposite to cow's milk (4\%) (Božanić, 2002). For the production of Camembert, numerous procedures were developed. Also, there are some changes in the chemical regime and different "recipes" are used (Salvadori del Prato, 2001; Perko et al., 2002; PopovicVranješ et al., 2002). Researches are not considering enough goat's milk and Camembert cheese. The target of this paper is to produce goat's milk which is healthy, safe and has good quality and is suitable for cheese production. A further interest is in the study on the influence of the characteristics of goats' milk quality and production technology on Chamembert type goat cheese.

\section{MATERIAL AND METHODS}

Milk was taken from a well equipped farm in Indjija which has about 200 goats of the German doe race, used for milking. The control for antibiotic residues in the milk was done with Delvotests SP. Counting of somatic cells was carried out on the apparatus Coulter Counter. The research of other residua in milk was performed with the following methods: radioactive elements by gamma spectrophotometry, heavy metals by atomic absorption spectrofotometry (AAS), mycotoxins on thin layer hromography (TLC) and pesticides by liquid chromatography. The fatty acid profile was determined with the method JUS E.K8.038. and the physical-chemical components of milk by standard protocols according to Ordinance No. 32/83. In the samples of raw goat's milk and in cheese samples the presence of Listeria monocytogenes and Bacillus cereus was studied. Mycrobiotic regulative was worked according to the methods from Ordinance No. 25/80. Listeria monocytogenes was determined with the method ISO (11290-1:1:1996/Amd.1), and Bacillus cereus according to IDF 181:1998. The process of cheese making is shown on Figure 1. which includes also the control points (CP).

The production of cheese according to French technology (Veisseyre, 1975 ) is adapted to conditions in the industrial diary production Selekt Milk from 
Acta Veterinaria (Beograd), Vol. 58. No. 5-6, 521-529, 2008.

Popović-Vranješ Anka et al.: The quality influence of goat milk and technology

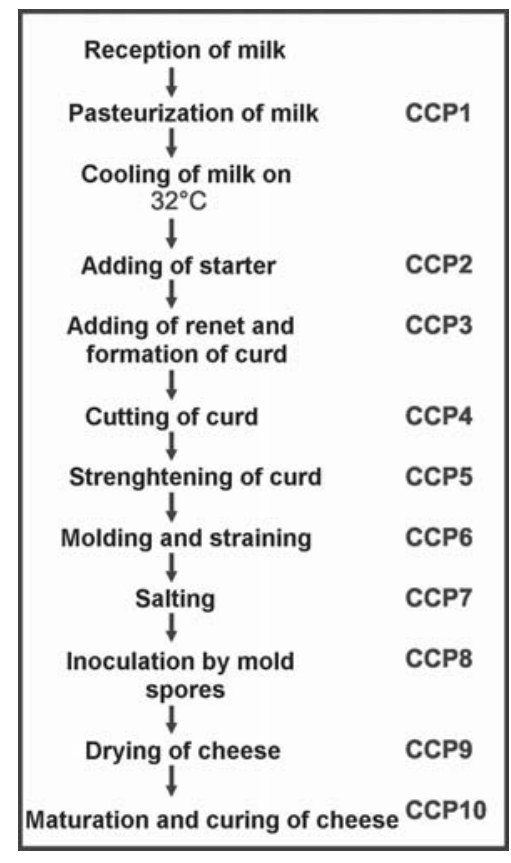

Figure 1. Diagram of the course of production cheese (Kosikowski et al, 1997. modif.)
Indjija. It was done in 12 production phases with the application of HACCP system (Hazard Analysis and Critical Control Points) in 2007.

After the pasteurisation process $\left(72^{\circ} \mathrm{C} / 15^{\prime \prime}\right)$, the milk was cooled at $32^{\circ} \mathrm{C}$. Calcium chloride was added (0.04\%) and after steering, starter cultures: TA052 (Streptococcus thermophilius, $0.5 \mathrm{gr} / 100 \mathrm{~L}$ and MM100 (Lactococcus lactis ssp. lactis, lactococcus lactis ssp. Cremoris, Lactoccoccus lactis ssp. Lactis biovar diacetyllactis, 4gr/100L). After sour fermentation molds (Geotrichum candidum $0.11 \mathrm{gr} / 100 \mathrm{~L}$ and Penicillium candidum $0.17 \mathrm{gr} / 100)$ and rennet (1.6 gr/100) were added.

The cultures and molds are produced by Texel, Rhodia Food, France and the rennet by Caglio Clerici, Italy. The coagulation of milk was performed for about 1 hour. The formed curdle was cut with knifes (2 cm spaced) and steered. Afterward the curdle was put into molds and was strained for the next 15-18 hours. When the cheese was ripe enough, it was turned every 12 hours on room temperature from $18-20^{\circ} \mathrm{C}$. After finishing the process of straining, the cheese was put into brine with 18-20\% of salt (from 125 up to $150 \mathrm{~g}$ of cheese stays into the brine from 50 up to $80 \mathrm{~min}$.). After salting, the cheese was dried for two days at $18^{\circ} \mathrm{C}$ (RV $\left.70-80 \%\right)$. Inoculation of the cheese with the mold Penicillium candidum was done in a water suspension, and after that the cheese was dried for two days and than put into chambers to ripen $10-12$ days at $12-13^{\circ} \mathrm{C}$ at RV of $90-95 \%$. After maturation, the cheese was packed and the cheese was tested after production (2-3 days), and then after 15, 30 and 45 days of maturation. The cheese becomes mature usually after 21-35 days. The statistical research was done according to Zizic et al. (2006).

\section{RESULTS AND DISCUSSION}

It is well known that from unhygienic goat milk we can not get good cheese, that is why on farms is necessary to have hygienic conditions which provide safe and good quality milk. This attitude resulted in UBB (the total number of bacteria) being $4-20 \times 10^{3} / \mathrm{mL}$ and the number of somatic cells from $230 \times 10^{3}-390 \times 10^{3}$, which is under the demands 92/46/EEC (Table 1). 
Table 1. Total number of bacteria and somatic cells in raw goat's milk

\begin{tabular}{|l|c|c|}
\hline $\begin{array}{l}\text { Statistical } \\
\text { parameters }\end{array}$ & $\begin{array}{c}\text { UBB* } / \mathrm{mL} \\
\text { in raw milk }\end{array}$ & $\begin{array}{c}\text { Number of } \\
\text { somatic cells/mL }\end{array}$ \\
\hline \hline $\mathrm{N}$ & 12 & 12 \\
\hline $\mathrm{X}^{\star}$ & $1.2 \times 10^{3}$ & $297 \times 10^{3}$ \\
\hline Xmin. & $4 \times 10^{3}$ & $230 \times 10^{3}$ \\
\hline Xmax. & $20 \times 10^{3}$ & $390 \times 10^{3}$ \\
\hline
\end{tabular}

*UBB - Number of somatic cells; $\mathrm{X}$ - mean value; $\mathrm{N}$ - number of samples

Pathogenic microorganisms are not found according to the Ordinance No. $26 / 93$, as well as the pathogenic Listeria mnocytogenes and Bacillus cereus. The chemical contents of milk ( $\left.{ }^{\circ} \mathrm{SH}\right)$ and $\mathrm{pH}$ values are shown in Table 2.

Table 2. Chemical composition, acidity and $\mathrm{pH}$ value

\begin{tabular}{|l|c|c|}
\hline Portion (\%) & $\mathrm{X} \pm \mathrm{s} . \mathrm{d}^{*}$ & $\mathrm{CV}(\%)$ \\
\hline \hline Milk fat & $3.20 \pm 0.10$ & 7.79 \\
\hline Dry matter & $11.27 \pm 0.47$ & 4.13 \\
\hline Dry matter without fat & $8.07 \pm 0.28$ & 3.45 \\
\hline Proteins & $2.99 \pm 0.17$ & 5.73 \\
\hline Casein & $2.36 \pm 0.11$ & 8.55 \\
\hline Lactose & $4.31 \pm 0.20$ & 6.02 \\
\hline Mineral matters & $0.77 \pm 0.053$ & 6.94 \\
\hline Acidity, oSH & $7.12 \pm 0.61$ & 7.58 \\
\hline pH value & $6.57 \pm 0.07$ & 1.13 \\
\hline
\end{tabular}

${ }^{*} \mathrm{X}$ - mean value; s.d - standard deviation; CV (\%) - coefficient of variation

The sampled milk did not contain residues of antibiotics, mycroxine, pesticide, heavy metals and radionuclides. The composition of the milk samples is in accordance with the results obtained by St-Gelais et al. (2002), where in the milk of the doe race, lower contents of protein, fats and lactose were found.

The relation of fat / casein was 1:0.737, and such milk is chemically suitable for cheese production (Scott, 1986). The souring of raw milk was in agreement to Ordinance No. 26/2002. and was in the range from $6.5-7.2{ }^{\circ} \mathrm{SH}$, and $\mathrm{pH}$ value form 6.40 to 6.59 . The contents of middle chain meat fatty acids was $15.31 \%$, which is much more from the quantity which is in cow's milk, and less than the quantity mentioned by Souci et al. (2000) and Bozanic (2002) in goat's milk. This is probably due to the influence of breed and feeding of goats during the study. The long chain fatty acids in goat's milk were present in $73.17 \%$, which is lower than cow's milk. The part of saturated fatty acids was $65.02 \%$ and half saturated $26.69 \%$. Among half saturated fatty acids in the goat milk samples was linol acid 
(3.1\%). According to the results of Jahreis et al. (1999) the contents of linol acid depend of the season being the lowest in the winter months. Goat's milk has the lowest contents of conjugated linol acid compared with other ruminants. Only human milk has an even lower value of this acid (Souci et al., 2000). In global, the presence of the fatty acidy is shown in Figure 2.

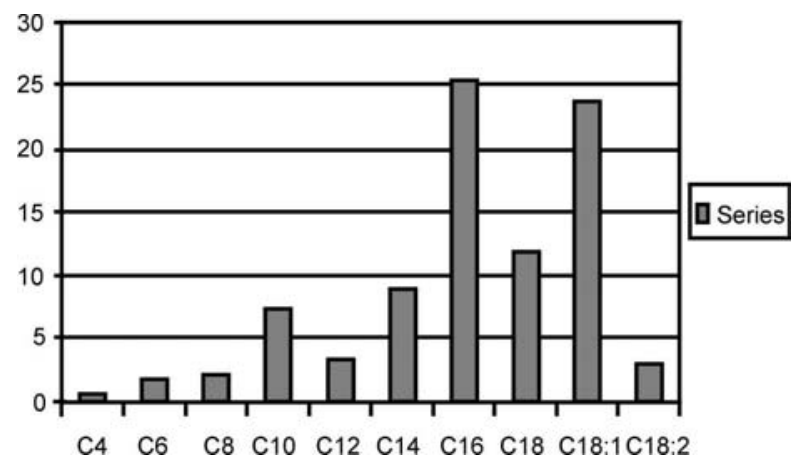

Figure 2. Presence of fatty acids in goat's milk

After the biological maturation of milk $(\mathrm{pH}$ 6.38-6.55, and sourness 7.4 to $7.6^{\circ} \mathrm{SH}$ ) rennet was added and after finishing coagulation, the curdle was cut. The curdle was cut in uniform parts and appropriate sizes, which provides easy separation of the whey. In the moment of curdle transport into molds for filtration, the $\mathrm{pH}$ of the whey was 6.26-6.53 and the sournes 5.4-6.0 $\mathrm{SH}$. In Cambembert cheese technology, the separation of the curdle grain from the whey starts immediately after curdle formination and practically it ends by placing it into the chambers in order to ripen. This phase is very important and basic for the success of production of high cheese quality (Ghitti, 1990), $\mathrm{pH}$ of cheese before salting was in the interval 4.9-5.1, and sourness $56.00-60.00^{\circ} \mathrm{SH}$.

Implementation of the HACCP system in cheese production is important because it assures a healthy and safe production (Popovic-Vranjes et al., 2005). Because it is an unstable product (Fox, 1993), critical control points of production were clearly determined thus eliminating hazards.

There were some technical problems during the distribution of the whey into the molds, which affected the dispersion of the weight (Figure 3). In modern continual lines the distribution of the whey is uniform.

Figure 3 shows the changes during the process of ripening, which always happens gradually. After 6-7 days of maturation, progressive souring occours and developed of P. camemberti starts, and soon it covers the whole surface. The texture changes rapidly in the first 12 days of maturation, after which the cheese can be packed.

The development of the mold urges the neutralisation of the dough which becomes soft, especially under the core. Due to proteolyses the dough becomes 
soft after 30 days and thereof creamy when the maturation comes to the "heart" of the cheese. As the ripeness advanced the texture of the cheese is at first elastic and then like creamy (after 35 days) and sometimes almost half liquid (45 days). The cheese becomes mature usually after 20-35 days.

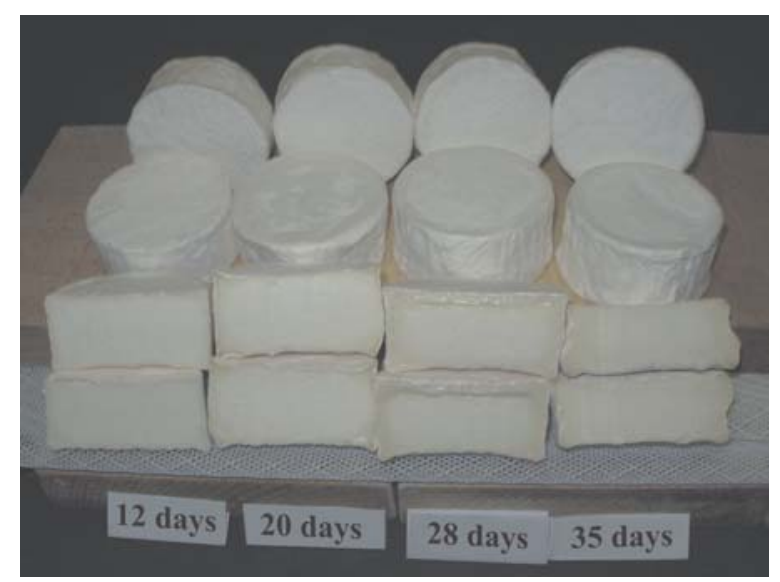

Figure 3. Changes of apperance and texture of cheese during maturation

From the results in the Table 3, it can be seen that based on the contents of fat, dry matter and moisture, the produced cheese, according to Ordinance No. $26 / 2002$ belongs to a group of soft (61-69\% of moisture in the material without fat) and half fat cheeses (45-50\% fats in the dry material), and in ripeness up to 30 days. The changes which appeared in the next period of maturation (45 days), can be controlled by packaging the cheese on time and keeping it at lower temperatures $\left(1^{\circ} \mathrm{C}\right)$.

The presence of water after the maturation of 12 days was $70.87 \pm 1.20 \%$, and after 30 days $67.71 \pm 0.26 \%$, which is in accordance to the biological characteristics of soft cheese. A further decrease of water content during maturtion (after 45 days $61.57 \pm 2.52 \%$ ) can be stopped by the packing the cheese on time. The moulds are showed like very halotolerant, because the presence of salt in the cheese was from $2.14 \pm 0.21 \%$ up to $2.4 \pm 0.42 \%$ and it stimulated their development which resulted with the fine cheesy taste. Biochemical changes during the process of ripening are shown in Table 4.

The sourness and $\mathrm{pH}$ change during the process of ripening and their influence on the texture of the cheese is very important. The starting $\mathrm{pH}$ of the cheese was $4.7 \pm 0.17$ and the texture of the cheese was brittle. After some 30 days, when the $\mathrm{pH}$ of the environment was about $6.10 \pm 0.17$ the texture of the whole cheese was half soft. The activity of the plasmas is growing with rising of the $\mathrm{pH}$, especially at the cheese surface (Lawrance et al., 1987). During ripening it starts to increase the dissolved nitrogen to an average value from $0.35 \pm 0.21$ to $0.94 \pm 0.20 \%$ 
and connected with that is the coefficient of ripeness $27.31 \pm 2.20 \%$ after the 30 days. After 45 days intensive proteolyses of the protein starts $(69.15 \pm 3.35 \%$ the coefficient of ripeness) and little native protein is left. During ripening the yeasts rapidly ferment the lactose and after 30 days of ripening, its quantity was reduced for more than $50 \%$ from the starting value. In the sensory view, the cheese has the appropriate characteristics for this kind of cheese. The return of the cheese was around $13.95 \%(7.17 \mathrm{~L}$ milk/kg cheese) which is in accordance with results of Tonkovic et al. (2003). The distribution and selling of cheese in the type of Camembert has to be on $2-4^{\circ} \mathrm{C}$. In the microbiological view the tested cheese was microbiologically correct according to the Ordinance No. 26/93 and there were no Listeria monocytogenes and Bacillus cereus present.

Table 3. Chemical changes of cheese during maturation

\begin{tabular}{|l|c|c|c|c|}
\hline \multicolumn{1}{|c|}{$\mathrm{N}=12$} & 2 days & 12 days & 30 days & 45 days \\
\hline Percentage $(\%)$ & $\mathrm{X} \pm \mathrm{s.d}$ & $\mathrm{X} \pm \mathrm{s.d}$ & $\mathrm{X} \pm \mathrm{s} . \mathrm{d}$ & $\mathrm{X} \pm \mathrm{s.d}$ \\
\hline \hline Milk fat & $18.03 \pm 1.25$ & $20.33 \pm 3.33$ & $23.83 \pm 2.89$ & $28.17 \pm 2.36$ \\
\hline Dry matter & $39.03 \pm 2.47$ & $43.51 \pm 2.81$ & $48.00 \pm 1.84$ & $55.70 \pm 4.75$ \\
\hline Fat in dry matter & $43.98 \pm 1.76$ & $46.54 \pm 1.06$ & $47.7 \pm 1.12$ & $50.57 \pm 0.15$ \\
\hline $\begin{array}{l}\text { Moisture in dry } \\
\text { matter without fat }\end{array}$ & $74.63 \pm 2.73$ & $70.87 \pm 1.20$ & $67.71 \pm 0.26$ & $61.57 \pm 2.52$ \\
\hline Mineral matters & $3.83 \pm 1.24$ & $3.95 \pm 1.33$ & $4.22 \pm 1.91$ & $4.46 \pm 1.73$ \\
\hline Kitchen salt & $2.14 \pm 0.21$ & $2.20 \pm 0.25$ & $2.25 \pm 0.38$ & $2.40 \pm 0.42$ \\
\hline
\end{tabular}

${ }^{*} \mathrm{X}$ - mean value; s.d - standard deviation

Table 4. Biochemical changes of cheese during maturation

\begin{tabular}{|l|c|c|c|c|}
\hline \multicolumn{1}{|c|}{$\mathrm{N}=12$} & 2 days & 12 days & 30 days & 45 days \\
\hline Percentage $(\%)$ & $\mathrm{X} \pm \mathrm{s} . \mathrm{d}^{*}$ & $\mathrm{X} \pm \mathrm{s} . \mathrm{d}$ & $\mathrm{X} \pm \mathrm{s.d}$ & $\mathrm{X} \pm \mathrm{s.d}$ \\
\hline \hline Acidity $\mathrm{SH}$ & $77 \pm 7.79$ & $52.27 \pm 13.61$ & $40.2 \pm 13.22$ & $46.4 \pm 14.99$ \\
\hline $\mathrm{pH}$ value & $4.78 \pm 0.17$ & $5.59 \pm 0.43$ & $6.10 \pm 0.17$ & $6.56 \pm 0.03$ \\
\hline Proteins & $16.98 \pm 1.75$ & $19.36 \pm 1.37$ & $21.91 \pm 0.52$ & $23.72 \pm 1.55$ \\
\hline Total $\mathrm{N}$ & $2.66 \pm 0.27$ & $3.03 \pm 0.22$ & $3.43 \pm 0.08$ & $3.72 \pm 0.24$ \\
\hline Soluble N & $0.35 \pm 0.21$ & $0.70 \pm 0.02$ & $0.94 \pm 0.20$ & $2.57 \pm 0.16$ \\
\hline Lactose & $1.02 \pm 0.13$ & $0.78 \pm 0.69$ & $0.44 \pm 0.70$ & $0.18 \pm 0.11$ \\
\hline $\begin{array}{l}\text { Coefficient of } \\
\text { maturity }\end{array}$ & $10.86 \pm 4.45$ & $23.49 \pm 0.16$ & $27.31 \pm 2.20$ & $69.15 \pm 3.35$ \\
\hline
\end{tabular}

* X - mean value; s.d - standard deviation

ACKNOWLEDGEMENTS

This work was part of the project BTN 351007B, financed by the Serbian Ministry of Science. 
Address for correspodence:

Dr Anka Popović-Vranješ

Agricultural Faculty

Department of Animal Science

Trg Dositeja Obradovica 8,

21000 Novi Sad, Serbia

E-mail: vranjes@polj.ns.ac.yu

\section{REFERENCES}

1. Alichanidis E, Polychroniadou A, 1997, Special features of dairy products from ewe and goat milk from the physicochemical and organoleptic point of view, Sheep Dairy News, 14, 1, 11-8.

2. Attaie R, Richter RL, 2000, Size distribution of fat globules in goat milk, J Dairy Sci, 83, 5, 940-4.

3. Božanić R, Tratnik Ljubica, Drgalić I, 2002, Goat's milk: characteristics and possibility, Dairy, 52, 3, 207-37.

4. Ćinkulov Mirjana, Trivunović Snežana, Krajinović M, Popović-Vranješ Anka, Pihler I, Porcu K, 2007, Characteristics of milk traits in the first three lactations of German fawn goats, Contemp agricul 56,1-2, 32-6, Novi Sad.

5. European Community, Council Directive EEC 92/46, 1992, Hygienic rules for the production and marketing of raw milk, heat treated milk and products based on milk, L 268, 14/9/92.

6. Fox PF, 1993, Cheese: an overview, in Cheese: Chemistry, Physics and Microbiology, Ed. Chapman \& Hall, London, 1-36.

7. Ferh PM, Delage J, 1973, Effet du niveau eenegetique de la ration sur l'utilisation par la glande mammaire de chevre de l'acetate comme precurseur des acides gras du lait, CR Acad Sc Paris, 276, Serie D, 3449-52.

8. Ghitii C, 1990, Latte 15, 365 .

9. International Dairy Federation, 1998, Reference method for the detection of Bacillus cereus 181.

10. International Standards Organisation, 1996, Method for the detection of Listeria monocytogenes 11290-1, 1996/Amd.1.

11. Jahreis G, J Fritsche J, Mockel P, F Schone F, Moller U, Steinhart H, 1999, The potential anticarcinogenic conjugated linoleic acid, cis-9, trans-11 C18:2, in milk of different species: cow, goat, ewe, sow, mare, woman, Nutrition Research 19, 1541-9.

12. Kosikowski FV, Mystry W, 1997, Cheese and fermented milk foods, 2, 3rd Edition, Edwards Brothers Inc, Ann Arbor, Michigan, USA.

13. Lawrence RC, Creamer LK, Gilles J, 1987, Cheese ripening technology, J Dairy Sci, 70, 1748-60.

14. Ordinance about methods of working of microbiological analyses and superanalyses of sustaining food (SI. list SFRJ No. 25/80).

15. Ordinance about quality and other requests for milk, dairy products and starter culture (SI. list SRJ No.26/2002).

16. Ordinance about methods of sampling and methods of chemical and physical analyse milk and dairy products, (SI. list SFRJ No. 32/83).

17. Ordinance of microbiological propriety of food in trading (SI. list SFRJ No. 26/93).

18. Perko $B, 2002$, Lactose fermentacion at Camembert, made by classic and stabilised tehnology, Dairy, 52, 1, 5-18.

19. Popović-Vranješ Anka, Krajinović M, Ostojić M, Pljevaljčić Olivera, 2005, Introduction of HACCP in the production of goat's cheeses, Symposium with international participation "Production and processing of goat's milk", Beograd, Proceeding of works, 67-74.

20. Popović-Vranješ Anka, Todorić Ružica, Očenaš Ljudmila, 2002, Importance of production Camembert cheese for expansion assortment our cheeses, Food ind, 14, 1-2, 56-60, Novi Sad.

21. Regulative EU. $2073 / 2005$.

22. Scott $R, 1986$, Cheesemaking practice, Elsevier Science Publishing, England.

23. Souci SW, Fachmann W, Kraut H, 2000, Die Zusammensetzung der Lebens-mittel, Nährwerttabellen, 5 Aufl, Stuttgart: Wissenschaftliche Verlagsgesell-schaft. 
Acta Veterinaria (Beograd), Vol. 58. No. 5-6, 521-529, 2008.

Popović-Vranješ Anka et al.: The quality influence of goat milk and technology

of production on the characteristic of the goat milk cheese of the Camembert type

24. Salvadori del Prato Ottavio, 2001, Trattato di Tecnologia casearia, Edagricole-Edizione Agricole della Calderini, Bologna 735-7.

25. St-Gelais Daniel, Oild Baba Ali, Sophie Turcot, 2002, Composition of Goat's milk and processing suitability.

26. Tonković K, Gregurek Ljerka, Božanić Rajka, 2003, Manufacturing of Camembert type cheese made from goat's and cow's milk and their mixtures, Dairy, 53, 4, 309-24.

27. Veisseyre $R, 1975$, Technologie du lait, La Maison rustique, Paris.

28. Žižić M, Lovrić M, Pavličić D, 2006, Methods of statistical analyse, Faculty of Economy, Belgrade.

\title{
UTICAJ KVALITETA KOZJEG MLEKA I TEHNOLOGIJE IZRADE NA OSOBINE KOZJEG SIRA U TIPU CAMEMBERT-a
}

\author{
POPOVIĆ-VRANJEŠ ANKA, JOVANOVIĆ S, SAVIĆ MILA, KRAJINOVIĆ M, \\ KASALICA ANKA, MIOČINOVIĆ DRAGICA i KECMAN JELENA
}

\section{SADRŽAJ}

Svrha rada je bila da se obezbedi kvalitetno kozje mleko i proizvede kozji sir u tipu Cammembert-a. Rezultati rada pokazuju da je kod sirovog mleka ukupan broj bakterija bio od $4 \times 10^{3}$ do $20 \times 10^{3} / \mathrm{ml}$, a broj somatskih ćelija od $230 \times 10^{3}$ do $390 \times 10^{3} / \mathrm{ml}$. Nisu nađene bakterije Listeria monocytogenes $i$ Bacillus cereus. Mleko nije sadržavalo rezidue antibiotika, mikotoksina, pesticida, teških metala i radionuklida. U higijenskom pogledu mleko je bilo bezbedno. Mleko nemačke srnaste rase koza (stajski načina držanja) je imalo 3,2 $\pm 0,10 \%$ mlečne masti i blag ukus i miris po kozjem. Udeo srednjolančanih masnih kiselina $\left(C_{6}-C_{12}\right)$ je bio $15,31 \%$, a kaprične kiseline 6,29 \%. Polinezasićenih masnih kiselina je bilo $26,69 \%$ u okviru kojih je bilo linolne kiseline 3,1 \%. Na osnovu sadržaja proteina kao i ostalih pokazatelja sastava i fizičko-hemijskih osobina, mleko je tehnološki bilo pogodno za sir. Izbor starter kultura MM100 i TA052 kao i plesni Geotrichum candidum i Penicillium camemberti i provedenog tehnološka procesa uz implementaciju HACCP sistema, omogućuli su dobijanje bezbednog sira, karakterističnih osobina. 